Brit. Heart f., 1966, 28, 740.

\title{
Respiratory Effects of Intravenous Lobeline in Normal Subjects and in Patients with Mitral Stenosis
}

\author{
ISRAEL BRUDERMAN, SHLOMO STERN, AND KARL BRAUN \\ From the Cardiopulmonary Laboratory and Department of Internal Medicine B, Hadassah University Hospital and \\ Hebrew University-Hadassah Medical School, ferusalem, Israel
}

Patients with mitral stenosis are known to have a diminished ventilatory response to inhalation of carbon dioxide, as compared with normal subjects. Reduced responsiveness of the respiratory centre (Pauli, Noe, and Coates, 1960) and/or altered mechnical properties of the lungs are assumed to be responsible for this change (Bruderman, Braun, and Rogel, 1965). The ventilatory response to $\mathrm{CO}_{2}$ inhalation is mediated partly through peripheral chemoreceptors (Heymans, Bouckaert, and Dautrebande, 1930), and the possibility of decreased activity of these receptors in the presence of mitral stenosis has not been investigated.

In the present study, designed to determine the role of the peripheral chemoreceptors in healthy subjects and in patients with mitral stenosis, hyperventilation was produced by intravenous administration of small doses of lobeline. This drug in small doses stimulates only the peripheral chemoreceptors, and not the respiratory centre (Liljestrand, 1951). As reports of the effect of lobeline on bronchial smooth muscle tone have been contradictory (Dautrebande et al., 1948; Daly and Schweitzer, 1951; Nadel and Widdicombe, 1962, 1963), its effect on the pulmonary mechanics in normal subjects and in patients with mitral stenosis was also investigated.

\section{SUBJECTS AND METHODS}

Ten healthy subjects and ten patients with mitral stenosis were studied. The control group consisted of 7 men and 3 women, aged 22 to 27 years. The group of patients consisted of 8 women and 2 men, aged 20 to 49 years. Mitral stenosis was diagnosed from the physical findings, radiological examination, and the electrocardiogram. All patients were in sinus rhythm, and no signs of systemic venous congestion were present. All underwent right heart catheterization, and the right atrial mean pressure and right ventricular end-diastolic pressure were normal. The pulmonary artery systolic pressure ranged between 34 and $48 \mathrm{~mm}$. Hg, the diastolic between 20 and $32 \mathrm{~mm}$. $\mathrm{Hg}$, and the mean pulmonary wedge pressure ranged between 12 and $29 \mathrm{~mm}$. $\mathrm{Hg}$. In five of the patients the cardiac output was measured by the Fick method; the calculated cardiac index ranged between $2.41 . / \mathrm{min} . / \mathrm{m} .{ }^{2}$ and $3.11 \mathrm{l} / \mathrm{min} . / \mathrm{m} .{ }^{2}$. The functional capacity of the patients was Class II or III according to the classification of the New York Heart Association.

All subjects were studied in the sitting position, with a Cournand needle in the left brachial artery and a rubber balloon in the lower third of the osophagus. After a rest period of five minutes, an arterial blood sample was withdrawn, and the resting minute volume (V), lung compliance $\left(\mathrm{C}_{\mathrm{L}}\right)$, and total lung resistance (TLR) were determined. Through a right antecubital vein, lobeline ${ }^{\star}(3 \mathrm{mg}$. diluted with normal saline to $6 \mathrm{ml}$.) was rapidly injected, and V, $\mathrm{C}_{\mathrm{L}}$, and TLR were recorded continuously during the subsequent 4 minutes. A further arterial blood sample was obtained at 2 minutes.

$\mathrm{C}_{\mathrm{L}}$ and TLR were determined by the method of Mead and Whittenberger (1953). Flow, volume, and pressure were recorded on a 4-channel Sanborn M 150 direct writer. Air flow was measured with a Sanborn pneumotachograph and Statham differential strain gauge transducer, and the volume signal was obtained by integration of the flow signal. The transpulmonary pressure was measured with a Statham differential strain gauge transducer, one side of which was connected to the osophageal balloon and the other to the mouth. The outputs of the above parameters were also connected to a cathode ray oscilloscope, and a pressurevolume trace was obtained. Electronically, a voltage proportional to the pressure needed to overcome the air-

\footnotetext{
^ Lobeline hydrochloride, Sandoz A.G.
} 
way resistance was subtracted from the pressure volume trace until a straight line resulted. The slope of this line represents $C_{L}$, and from the applied voltage TLR was calculated.

The arterial oxygen content and capacity and carbon dioxide content were measured by the method of Van Slyke and Neill (1924). The arterial carbon dioxide tension was obtained from the line charts of Van Slyke and Sendroy (1928) on the basis of the known blood $p \mathrm{H}$ and plasma carbon dioxide content.

\section{ReSUlts}

Healthy Subjects. The resting ventilatory measurements, as well as the calculated parameters and the corresponding values following intravenous injection of lobeline, are summarized in Table $\mathrm{I}$, and Fig. 1-4. As can be seen, the minute ventilation rose significantly from an average of 6.3 $1 . / \mathrm{min} . / \mathrm{m} .^{2}$ to an average of $15.01 . / \mathrm{min} . / \mathrm{m} .{ }^{2}$ Statistically this rise was significant and was mainly due to an increase in tidal volume. The TLR increased from a control value of $1.6 \mathrm{~cm} . \mathrm{H}_{2} \mathrm{O} / \mathrm{l}$./sec. to $3.7 \mathrm{~cm} . \mathrm{H}_{2} \mathrm{O} / \mathrm{l}$. $/ \mathrm{sec}$. within the first minute after lobeline injection, a change also found to be statistically significant. Within 4 to 5 minutes TLR returned gradually to the resting value. No change in $\mathrm{C}_{\mathrm{L}}$ was observed, the average value being 0.25 1. $/ \mathrm{cm} \cdot \mathrm{H}_{2} \mathrm{O}$.

The average arterial blood $\mathrm{O}_{2}$ saturation was 96 per cent, the average arterial $\mathrm{CO}_{2}$ tension 41 $\mathrm{mm} . \mathrm{Hg}$, and average $p \mathrm{H} 7 \cdot 39$. Two minutes after lobeline injection no significant changes were observed in these values.

Cough appeared in all subjects after a latent period of 4 to 6 seconds from the beginning of the injection, and lasted 6 to 18 seconds. No substernal burning sensation was experienced by any of these subjects.

Patients with Mitral Stenosis. The measurements of ventilation and mechanics of respiration before and after lobeline are summarized in Table II, and Fig. 1-4. It can be seen that the resting minute volume averaged $8.71 . / \mathrm{min} . / \mathrm{m} .{ }^{2}$ which is higher than the corresponding value in the healthy subjects; after lobeline it rose only to $9.81 . / \mathrm{min} . / \mathrm{m}^{2}$, a change not significant according to statistical evaluation. The average resting TLR was 3.6 $\mathrm{cm} . \mathrm{H}_{2} \mathrm{O} / \mathrm{l}$./sec., and after lobeline increased to $5.5 \mathrm{~cm} . \mathrm{H}_{2} \mathrm{O} / \mathrm{l}$. $/ \mathrm{sec}$. within the first minute, a statistically significant change. While the resting value was much higher than in normal subjects, the increment in TLR following the injection was almost of the same magnitude as in the healthy subjects. The resting $\mathrm{C}_{\mathrm{L}}$ was lower than in normal subjects, with an average of $0 \cdot 15 \mathrm{l} . / \mathrm{cm} . \mathrm{H}_{2} \mathrm{O}$, and did not change after lobeline administration.

The average arterial blood $\mathrm{O}_{2}$ saturation was 94

TABLE I

VENTILATORY STUDIES AND MECHANICS OF RESPIRATION OF NORMAL SUBJECTS

\begin{tabular}{|c|c|c|c|c|c|c|c|c|c|c|}
\hline & \multicolumn{2}{|c|}{ Respiratory rate/min. } & \multicolumn{2}{|c|}{$\begin{array}{l}\text { Tidal volume } \\
\text { (ml.) }\end{array}$} & \multicolumn{2}{|c|}{$\underset{\left(1 . / \mathrm{min} . / \mathrm{m}^{2}\right)^{\star}}{\operatorname{Minute}}$} & \multicolumn{2}{|c|}{$\begin{array}{l}\text { Total lung resistance } \\
\left(\mathrm{cm} . \mathrm{H}_{2} \mathrm{O} / 1 . / \mathrm{sec} .\right)\end{array}$} & \multicolumn{2}{|c|}{$\begin{array}{l}\text { Compliance of lungs } \\
\left(1 . / \mathrm{cm} \cdot \mathrm{H}_{2} \mathrm{O}\right)\end{array}$} \\
\hline & Control & $\begin{array}{c}30-60 \mathrm{sec} . \\
\text { after } \\
\text { lobeline }\end{array}$ & Control & $\begin{array}{c}\text { 30-30 sec. } \\
\text { after } \\
\text { lobeline }\end{array}$ & Control & $\begin{array}{c}30-60 \text { sec. } \\
\text { after } \\
\text { lobeline }\end{array}$ & Control & $\begin{array}{c}30-60 \text { sec. } \\
\text { after } \\
\text { lobeline }\end{array}$ & Control & $\begin{array}{l}30-60 \mathrm{sec} . \\
\text { after } \\
\text { lobeline }\end{array}$ \\
\hline 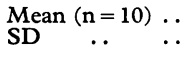 & $\begin{array}{l}17 \\
3 \cdot 7\end{array}$ & $\begin{array}{l}28 \\
15 \cdot 4\end{array}$ & $\begin{array}{l}670 \\
116\end{array}$ & $\begin{array}{l}960 \\
328\end{array}$ & $\begin{array}{l}6 \cdot 3 \\
1 \cdot 1\end{array}$ & $\begin{array}{c}15 \cdot 0 \\
8 \cdot 3\end{array}$ & $\begin{array}{l}1 \cdot 6 \\
0 \cdot 41\end{array}$ & $\begin{array}{l}3 \cdot 7 \\
1 \cdot 48\end{array}$ & $\begin{array}{l}0.25 \\
0.06\end{array}$ & $\begin{array}{l}0 \cdot 24 \\
0 \cdot 04\end{array}$ \\
\hline & \multicolumn{2}{|c|}{$p>0.05$} & \multicolumn{2}{|c|}{$\mathrm{p}<0.02$} & \multicolumn{2}{|c|}{$p<0.02$} & \multicolumn{2}{|c|}{$\mathrm{p}<0.01$} & & \\
\hline
\end{tabular}

^Volumes corrected to body temperature, ambient pressure, and saturated with water vapour (BTPS).

TABLE II

VENTILATORY STUDIES AND MECHANICS OF RESPIRATION OF PATIENTS WITH MITRAL STENOSIS

\begin{tabular}{|c|c|c|c|c|c|c|c|c|c|c|}
\hline & \multicolumn{2}{|c|}{ Respiratory rate/min. } & \multicolumn{2}{|c|}{$\begin{array}{l}\text { Tidal volume } \\
\text { (ml.) }\end{array}$} & \multicolumn{2}{|c|}{$\underset{\left(1 . / \mathrm{min} . / \mathrm{m}^{2}\right)}{\operatorname{Minute}}$} & \multicolumn{2}{|c|}{$\begin{array}{c}\text { Total lung resistance } \\
\left(\mathrm{cm} . \mathrm{H}_{2} \mathrm{O} / 1 . / \mathrm{sec} .\right)\end{array}$} & \multicolumn{2}{|c|}{$\begin{array}{c}\text { Compliance of lungs } \\
\left(1 . / \mathrm{cm} \cdot \mathrm{H}_{2} \mathrm{O}\right)\end{array}$} \\
\hline & Control & $\begin{array}{c}30-60 \text { sec. } \\
\text { after } \\
\text { lobeline }\end{array}$ & Control & $\begin{array}{c}30-60 \text { sec. } \\
\text { after } \\
\text { lobeline }\end{array}$ & Control & $\begin{array}{c}30-60 \text { sec. } \\
\text { after } \\
\text { lobeline }\end{array}$ & Control & $\begin{array}{c}30-60 \text { sec. } \\
\text { after } \\
\text { lobeline }\end{array}$ & Control & $\begin{array}{c}30-60 \text { sec. } \\
\text { after } \\
\text { lobeline }\end{array}$ \\
\hline $\begin{array}{l}\text { Mean }(n=10) \\
\text { SD } \quad . .\end{array}$ & 21 & $\begin{array}{r}25 \cdot 0 \\
6 \cdot 1\end{array}$ & $\begin{array}{l}670 \\
358\end{array}$ & $\begin{array}{l}670 \\
358\end{array}$ & $\begin{array}{l}8 \cdot 7 \\
2 \cdot 9\end{array}$ & $\begin{array}{l}9 \cdot 8 \\
4 \cdot 1\end{array}$ & $\begin{array}{l}3.6 \\
1.09\end{array}$ & $\begin{array}{l}5 \cdot 5 \\
2 \cdot 22\end{array}$ & $\begin{array}{l}0.15 \\
0.05\end{array}$ & $\begin{array}{l}0.15 \\
0.06\end{array}$ \\
\hline & \multicolumn{2}{|c|}{$\mathrm{p}<0.05$} & & & \multicolumn{2}{|c|}{$p>0.05$} & \multicolumn{2}{|c|}{$\mathrm{p}<0.02$} & & \\
\hline
\end{tabular}

^Volumes corrected to body temperature, ambient pressure, and saturated with water vapour (BTPS). 


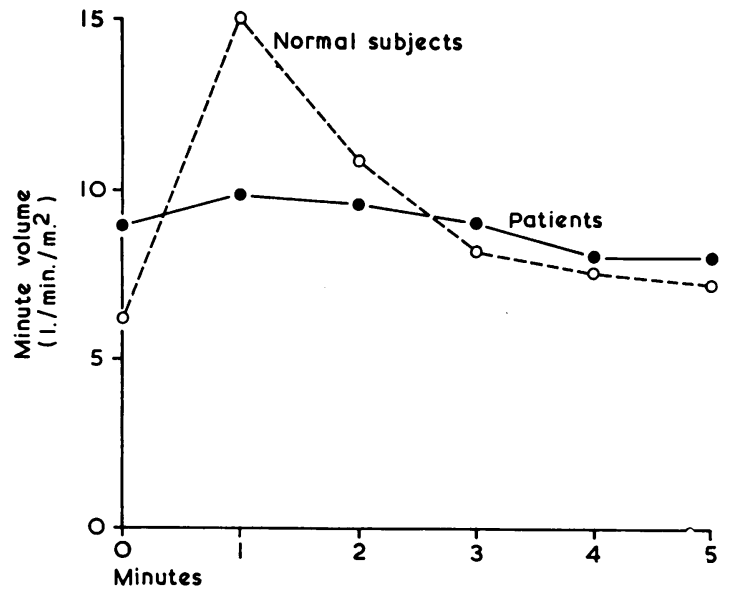

Fig. 1.-The change in minute ventilation after intravenous injection of $3 \mathrm{mg}$. lobeline is shown. Note the rise of minute volume in healthy subjects, but no rise in patients with mitral stenosis.

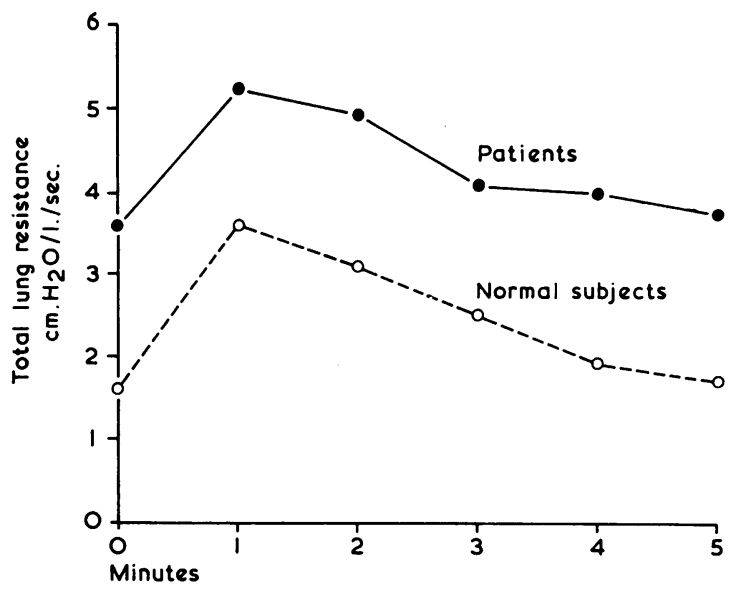

Fig. 2.-The changes in total lung resistance after lobeline administration in normal subjects and in patients with mitral stenosis. In both groups TLR rose significantly within the first minute.

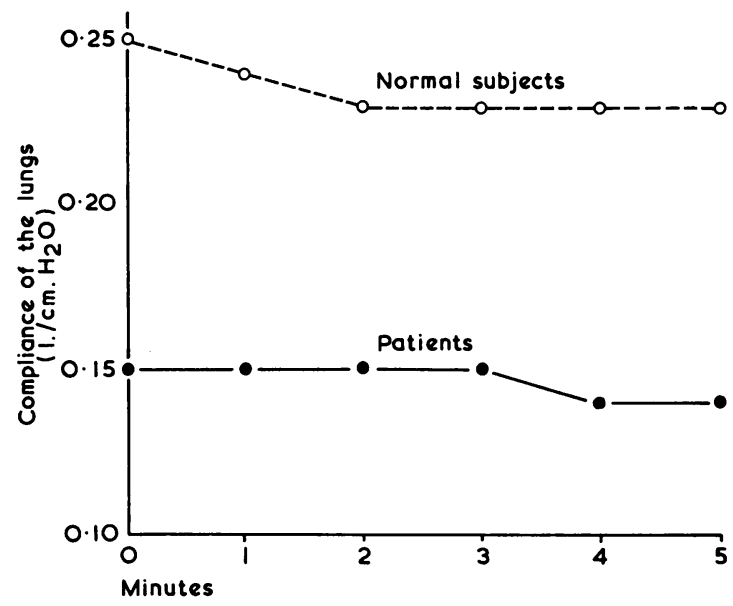

FIG. 3.-Lung compliance did not change significantly after lobeline.

per cent, the arterial $\mathrm{CO}_{2}$ tension was $39 \mathrm{~mm} . \mathrm{Hg}$,

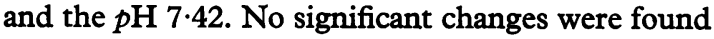
in these values after lobeline injection.

In contrast to the normal subjects, cough appeared in only 3 out of 10 patients after a latent period of 4.0 to 9.5 seconds, and lasted 4 to 11 seconds.

\section{Discussion}

From the results it is evident that, while in normal subjects an almost threefold increase in minute ventilation occurred after the intravenous injection of lobeline, in patients with mitral stenosis minute ventilation did not change significantly. These results resemble the diminished respiratory response of patients with mitral stenosis following $\mathrm{CO}_{2}$ breathing (Pauli et al., 1960; Bruderman et al., 1965). While $\mathrm{CO}_{2}$ breathing induces hyperventilation by a combined stimulatory effect on the respiratory centre and the peripheral chemoreceptors (Heymans et al., 1930), lobeline in small doses, as used in our experiments, produces hyperventilation through stimulation of the peripheral chemoreceptors only (Liljestrand, 1951). Therefore the lack of increase in minute ventilation in patients with mitral stenosis might indicate a decreased sensitivity in the patients' chemoreceptors. Decreased sensitivity of the peripheral chemo- 


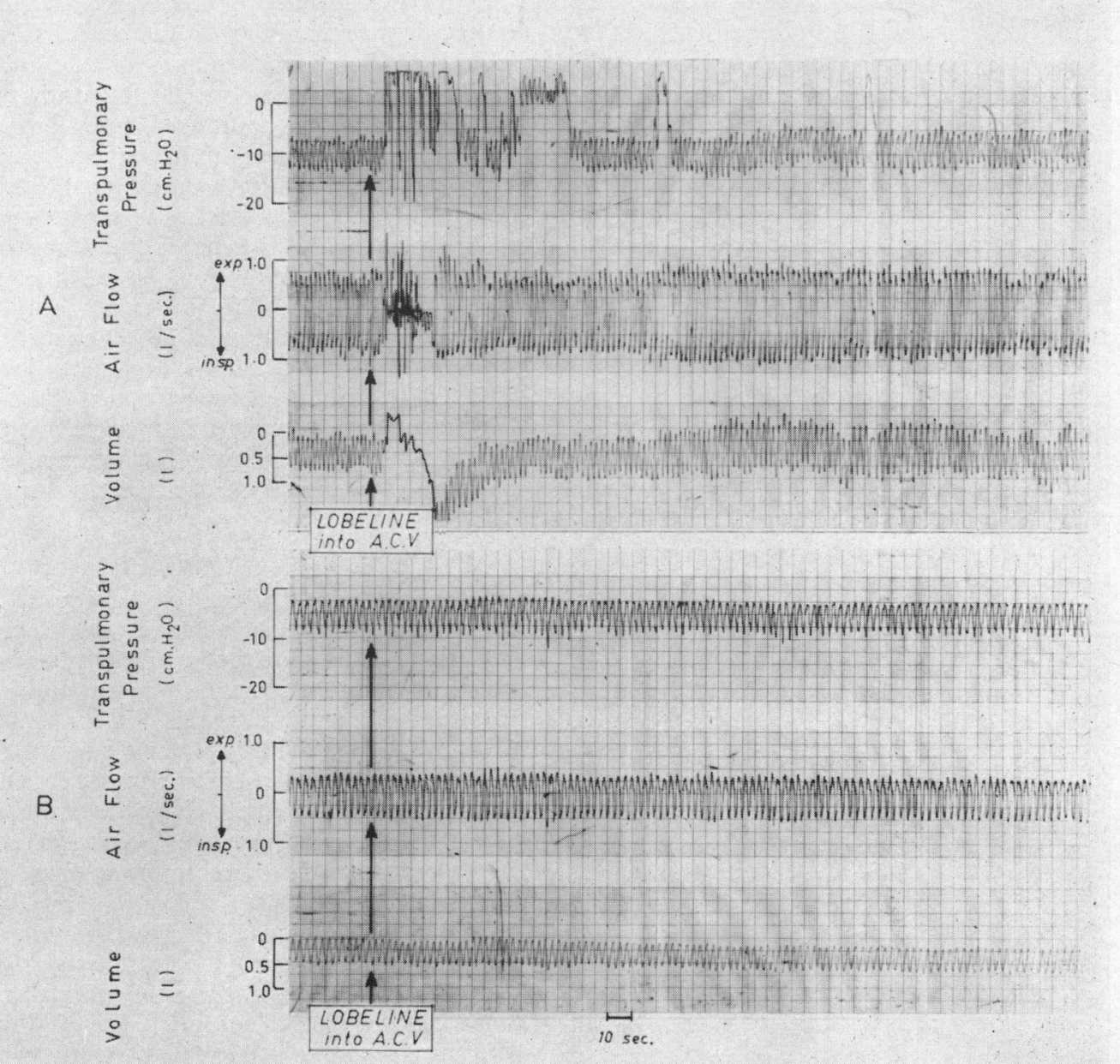

FIG. 4.-The effect of lobeline on cough in a normal subject (A) and a patient with mitral stenosis (B) is shown. Note the appearance of cough within 6 seconds in the normal subject, while no cough was noted in the mitral patient. The vertical arrow indicates the beginning of injection into the antecubital vein. Paper speed $1 \mathrm{~mm} . / \mathrm{sec}$.

receptors was recently described after prolonged residence at high altitude by Bainton, Carcelen, and Severinghaus (1965). These authors demonstrated in Andean natives, a decreased ventilatory response to acutely induced hypoxia, and related it to the chronic hypoxia present in these subjects. This factor can be excluded in our patients, since we found a normal arterial oxygen saturation in all of them. A decreased concentration of lobeline reaching the chemoreceptors in patients with mitral stenosis could be claimed as a cause for the decreased ventilatory response. However, all our patients were in sinus rhythm, had normal circulation time, the pulmonary arterial and wedge pressures were only slightly or moderately raised, and the cardiac output, measured in five of the patients, was found to be normal. Other investigators (Selzer, 1959; Braun, Rosenberg, and Schwartz, 1959) also described normal or only slightly reduced cardiac output in patients with a mild degree of mitral stenosis. This makes a reduced concentration of the drug reaching the chemoreceptors unlikely. We assume, therefore, that the chemoreceptor cells might have reduced sensitivity in these patients, though a change in the mechanical properties of the lungs of such patients might also play a part (White, Butler, and Donald, 1958; Bruderman et al., 1965). The causative factor leading to decreased sensitivity could not be identified by us. It may be related to the chronic hyperventilation of patients with mitral stenosis.

Daly and Schweitzer (1951) reported that lobeline 
administered intravenously causes bronchodilatation. A similar effect in normal subjects was reported after lobeline aerosol and was called "pneumodilatation" (Dautrebande et al., 1948). Nadel and Widdicombe $(1962,1963)$ demonstrated an increase in bronchial smooth muscle tone in dogs following stimulation of the peripheral chemoreceptors with nicotine or carbon dioxide. Our results in normal subjects confirmed the latter findings by demonstrating a statistically significant rise in the TLR lasting up to 4 minutes after the injection of lobeline. The increase in bronchial tone following lobeline was observed also in those patients with mitral stenosis who had no cough response to the drug. Cough alone is known to produce bronchoconstriction lasting up to one minute (Widdicombe, 1954), but this observation separates the bronchoconstrictive effect of lobeline itself from that of the cough.

The different response in TLR to $\mathrm{CO}_{2}$ breathing and to lobeline in patients with mitral stenosis is noteworthy. As previously reported (Bruderman et al., 1965), no change in TLR occurred in these patients following $\mathrm{CO}_{2}$ inhalation, while there was a marked rise in normal subjects; whereas, in the present study, after lobeline the increase in TLR in patients with mitral stenosis was of almost the same magnitude as in the healthy subjects. This difference may be due to different pathways of action of lobeline and $\mathrm{CO}_{2}$ on the bronchial smooth muscle.

The intravenous injection of lobeline is used to measure arm-to-aorta or arm-to-carotid circulation time by the interval elapsing from injection to the cough response (Berliner, 1940). Eckenhoff and Comroe (1951) reported that cough occurred within 8 seconds after intravenous injection of lobeline, and preceded hyperpnoea by several seconds. These authors suggested, therefore, that the cough receptors might be located in the respiratory tract and supplied by the pulmonary circulation. Our observation of cough in all 10 healthy subjects within four to six seconds after the injection, lends support to this suggestion. It is noteworthy that only 3 of the 10 patients with mitral stenosis experienced cough following the intravenous administration of $3 \mathrm{mg}$. lobeline. On the other hand, in another study by us (Stern, Bruderman, and Braun, 1966), the same amount of lobeline injected directly into the main pulmonary artery induced cough in all the six patients with mitral stenosis who received it. This route of administration obviously enhanced the concentration of the drug reaching the receptors located in the pulmonary circulation, which then sufficed to stimulate them. This observation may point to a decreased sensitivity of the cough-inducing receptors in patients with mitral stenosis. The pathological or functional changes of the pulmonary vascular bed caused by the pulmonary hypertension or alterations of the mechnical properties of the lungs may be responsible for this change.

In our study neither the healthy subjects nor the patients with mitral stenosis experienced substernal pain, while Eckenhoff and Comroe (1951) described this phenomenon in all the subjects studied by them. This difference may be explained by the large dose of lobeline used by these authors ( 5 to $7.5 \mathrm{mg}$.). Since, despite the lower dose of lobeline, explosive cough occurred in all our healthy subjects, the possibility exists that the pain receptors are distinct from the cough receptors and possess a higher threshold of sensitivity.

\section{SUMMARY}

Pulmonary ventilation, mechanics of respiration, and arterial blood gases were measured before and immediately after intravenous administration of $3 \mathrm{mg}$. lobeline in 10 normal subjects and 10 patients with mitral stenosis.

In the healthy subjects minute ventilation increased almost threefold after administration of this drug, while only a slight change was observed in patients with mitral stenosis. Decreased sensitivity of the peripheral chemoreceptors in these patients is therefore suspected.

Cough appeared in all healthy subjects 4 to 6 seconds after the injection, indicating that the cough receptors are located in the pulmonary circulation. Since cough appeared in only 3 out of 10 patients with mitral stenosis, a decreased sensitivity of these receptors may also be assumed in this disease.

Total lung resistance increased significantly both in normal subjects and patients with mitral stenosis after lobeline, thus demonstrating the bronchoconstrictor effect of this drug. No change in lung compliance occurred either in the healthy subjects or in patients with mitral stenosis.

The technical assistance of Messrs. Y. Katz and J. Fischer and Miss R. Berkowitz is gratefully acknowledged.

\section{REFERENCES}

Bainton, C. R., Carcelen, B. A., and Severinghaus, J. W. (1965). Carotid chemoreceptor insensitivity in Andean natives. F. Physiol (Lond.), 177, 30P.

Berliner, K. (1940). Use of alpha lobeline for measurement of velocity of blood flow. Arch. intern. Med., 65, 896.

Braun, K., Rosenberg, S. Z., and Schwartz, A. (1959). Central blood volume, cardiac output, and pulmonary vascular pattern in mitral stenosis. Amer. f. Cardiol., 3,40 . 


\section{Respiratory Effects of Intravenous Lobeline in Normal Subjects and in Patients with Mitral Stenosis 745}

Bruderman, I., Braun, K., and Rogel, S. (1965). Effect of $\mathrm{CO}_{2}$ inhalation on ventilation and mechanics of breathing in mitral disease. Brit. Heart f., 27, 177.

Daly, M. de Burgh, and Schweitzer, A. (1951). Reflex bronchomotor responses to stimulation of receptors in the regions of the carotid sinus and arch of the aorta in the dog and cat. F. Physiol. (Lond.), 113, 442.

Dautrebande, L., Alford, W. C., Higham, B., Downing, R., and Weaver, F. L. (1948). Studies on aerosols. V. Effect of dust and pneumodilating aerosols on lung volume and type of respiration in man. $\mathscr{f}$. appl. Physiol., 1, 339.

Eckenhoff, J. E., and Comroe, J. H., Jr. (1951). Blocking action of tetrætheylammonium on lobelin-induced thoracic pain. Proc. Soc. exp. Biol. (N.Y.), 76, 725.

Heymans, C., Bouckaert, J. J., and Dautrebande, L. (1930). Sinus carotidien et réflexes respiratoires. II. Influences respiratoires réflexes de l'acidose, de l'alcalose, de l'anhydride carbonique, de l'ion hydrogène et de l'anoxémie. Sinus carotidiens et échanges respiratoires dans les poumons et au dela des poumons. Arch. int. Pharmacodyn., 39, 400.

Liljestrand, G. (1951). The action of certain drugs on respiration. Brit. med.f., 2, 623.

Mead, J., and Whittenberger, J. L. (1953). Physical properties of human lungs measured during spontaneous respiration. F. appl. Physiol., 5, 779.

Nadel, J. A., and Widdicombe, J. G. (1962). Effect of changes in blood gas tensions and carotid sinus pressure on tracheal volume and total lung resistance to airflow. F. Physiol. (Lond.), 163, 13.

- , and - (1963). Reflex control of airway size. Ann. N.Y. Acad. Sci., 109, 712.

Pauli, H. G., Noe, F. E., and Coates, E. O. (1960). The ventilatory response to carbon dioxide in mitral disease. Brit. Heart $\mathcal{F}$., 22, 255.

Selzer, A. (1959). Hemodynamic sequelæ of sustained elevation of left atrial pressure. Circulation, 20, 243.

Stern, S., Bruderman, I., and Braun, K. (1966). Localization of lobeline-sensitive receptors in the pulmonary circulation in man. Amer. Heart. F., 71, 651.

Van Slyke, D. D., and Neill, J. M. (1924). The determination of gases in blood and other solutions by vacuum extraction and manometric measurement. I. $\mathcal{F}$. biol. Chem., 61, 523.

—, and Sendroy, J., Jr. (1928). Studies of gas and electrolyte equilibria in blood. XV. Line charts for graphic calculations by the Henderson-Hasselbach equation, and for calculating plasma carbon dioxide content from whole blood content. F. biol. Chem., 79, 781.

White, H. C., Butler, J., and Donald, K. W. (1958). Lung compliance in patients with mitral stenosis. Clin. Sci., $17,667$.

Widdicome, J. G. (1954). Respiratory reflexes from the trachea and bronchi of the cat. f. Physiol. (Lond.), 123, 55. 